\title{
Electrochemical Cells with Multilayer Functional Electrodes for NO Decomposition
}

\author{
Sergey Bredikhin ${ }^{1}$ and Masanobu Awano ${ }^{2}$ \\ ${ }^{1}$ Institute of Solid State Physic Russian Academy of Sciences, Chernogolovka, \\ ${ }^{2}$ Advanced Manufacturing Research Institute, National Institute of Advanced Industrial \\ Science and Technology (AIST), Shimo-shidami, Moriyama-ku, Nagoya \\ ${ }^{1}$ Russia \\ ${ }^{2}$ Japan
}

\section{Introduction}

Striking progress has recently been made in understanding the central role of nitrogen oxide radicals, $\mathrm{NO}_{\mathrm{x}}$, in atmospheric processes (Lerdau et al., 2000). $\mathrm{NO}_{\mathrm{x}}$ is implicated in the formation of acid rain and a tropospheric ozone (the principal toxic component of smog and a greenhouse gas) (Finlayson-Pitts, B.J. \& Pitts, J.N., 1997; Lerdau et al., 2000). The major known source of $\mathrm{NO}_{x}$ is fuel combustion and biomass burning. Air pollution by nitrogen oxides $\left(\mathrm{NO}_{x}\right)$ in combustion waste causes serious environmental problems in urban areas. The reduction of nitrogen oxide emissions has become one of the greatest challenges in environment protection (Libby, 1971; Nishihata et al., 2002). This is why the different methods of NOx decomposition are intensely studied by numerous groups from academic as well as industrial research laboratories (Garin, 2001; Parvulescu et al., 1998).

The main activities of scientific groups working in the field of $\mathrm{NO}$ decomposition are concentrated on the reduction of the NOx in the presence of $\mathrm{NH}_{3}, \mathrm{CO}, \mathrm{H}_{2}$ or hydrocarbons. These scientific groups have been tested a large number of categories of catalysts with a different ways of NO decomposition reactions. The main directions of the research can be described as follows.

First, the selective catalytic reduction of NO with ammonia, typical for chemical industrial plants and stationary power stations (Bosch \& Janssen, 1988; Janssen \& Meijer, 1993). The main step is the reduction on $\mathrm{NO}$ or $\mathrm{NO}_{2}$ to $\mathrm{N}_{2}$ and $\mathrm{H}_{2} \mathrm{O}$. Generally, liquid ammonia is injected in the residual gas before the catalytic reaction takes place.

$$
\begin{gathered}
4 \mathrm{NO}+4 \mathrm{NH}_{3}+\mathrm{O}_{2} \longrightarrow 4 \mathrm{~N}_{2}+6 \mathrm{H}_{2} \mathrm{O} \\
6 \mathrm{NO}+4 \mathrm{NH}_{3} \longrightarrow 5 \mathrm{~N}_{2}+6 \mathrm{H}_{2} \mathrm{O}
\end{gathered}
$$

Second, the catalytic reduction of NO in the presence of $\mathrm{CO}$ and/or hydrogen. These reactions are typical for the automotive pollution control. The use of $\mathrm{CO}$ or $\mathrm{H}_{2}$ for catalytic reduction was one of the first possibilities investigated in view of eliminating NO from automotive exhaust gas (Baker \& Doerr, 1964, 1965; Klimisch \& Barnes, 1972; Nishihata et al., 2002; Roth \& Doerr, 1961). 


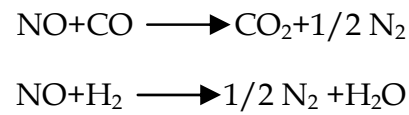

Third, the selective catalytic reduction of NO in the presence of hydrocarbons and more particularly methane, a method which has not yet reached industrial use but can be applied both for automotive pollution control and in various industrial plants (Armor, 1995; Hamada et al., 1991; Iwamoto, 1990; Libby, 1971; Miura et al., 2001; Sato et al., 1992).

Fourth, the direct decomposition of NO. The decomposition of NO would represent the most attractive solution in emission control, because the reaction does not require that any reactant be added to $\mathrm{NO}$ exhaust gas and could potentially lead to the formation of only $\mathrm{N}_{2}$ and $\mathrm{O}_{2}$ (Garin, 2001; Lindsay et al., 1998; Miura et al., 2001; Rickardsson et al., 1998).

The goal of this paper is to represent a fifth direction of an intense research effort focused on electrochemical cells for the reduction of $\mathrm{NO}_{x}$ gases due to the need to design an effective method for the purification of the exhaust gases from lean burn and diesel engines.

\section{Traditional type of electrochemical cells for NO decomposition}

Electrochemical cells have become an important technology, which contributes to many aspects of human life, industry and environment. Now it is understandable that the reduction of NOx emission can be achieved not only by catalytic NOx decomposition but also by electrochemical decomposition, where the removal of oxygen by a gaseous reducing reagent is replaced by the more effective electrochemical removal. Additional reducing reagents such as hydrocarbons, $\mathrm{CO}, \mathrm{H}_{2}$ or ammonia can lead to the production of secondary pollutants like oxygenated hydrocarbons, $\mathrm{CO}, \mathrm{CO}_{2}, \mathrm{~N}_{2} \mathrm{O}$ or ammonia or, even, as was often reported in the past, cyanate and isocyanate compounds.

Without coexisting oxygen the successful decomposition of $\mathrm{NO}$ gas into oxygen and nitrogen in a primitive electrochemical cell (Fig.1) was first demonstrated over 25 years ago (Gur \& Huggins, 1979; Pancharatnam et al., 1975). In 1975 Pancharatnam et al. (Pancharatnam et al., 1975) proposed to use for NO gas decomposition an electrochemical cell represented by the following cell arrangement

$$
\operatorname{Pt}(\text { Cathode }) \mid \text { YSZ } \mid \operatorname{Pt}(\text { Anode })
$$

On applying a voltage to such cells NO gas is directly reduced at the triple-phase boundary (tpb) (cathode - yttrium-stabilized zirconia (YSZ) - gas) forming gaseous $\mathrm{N}_{2}$ and solid -phase oxygen ions:

$$
2 \mathrm{NO}+4 \mathrm{e}^{-}+2 \mathrm{~V}_{\mathrm{O}}\left(\mathrm{ZrO}_{2}\right) \rightarrow \mathrm{N}_{2}+2 \mathrm{O}^{2^{-}}(\mathrm{YSZ})
$$

Under the external voltage the oxygen ions are transported through the solid electrolyte from cathode to anode and gaseous $\mathrm{O}_{2}$ is evolved at the anode.

Unfortunately, excess $\mathrm{O}_{2}$ in the combustion exhaust gas is adsorbed and decomposed at the $t p b$ in preference to the NO gas (Fig.1):

$$
\mathrm{O}_{2}+4 \mathrm{e}^{-}+2 \mathrm{~V}_{\mathrm{O}}\left(\mathrm{ZrO}_{2}\right) \rightarrow 2 \mathrm{O}^{2-}(\mathrm{YSZ})
$$


As a result, the additional ionic current though the cell associated with the oxygen ions produced due to this unwanted reaction (Eq.(3)) far exceeds the current associated with the desired reaction (Eq.(2)). In 1997 Hibino et al. (Hibino et al., 1997) has shown that at first stage the electrochemical oxygen pumping is carried out without $\mathrm{NO}$ decomposition, and that NO decomposition began at corresponding currents after the electrochemical oxygen pump is complete. As illustration Fig.2 shows the dependence of NO conversion on the value of the current passing through the two chambers cell at $1000 \mathrm{ppm}$ of NO without oxygen (Curve 1) and at $2 \%$ of Oxygen (Curve 2) in He (the balance) at gas flow rate $50 \mathrm{ml} / \mathrm{min}$. It is seen that in the presence of oxygen the decomposition of NO take place only when all oxygen should be pumped away from the near electrode area.

Recently, many attempts to improve the properties of electrochemical cells operating in the presence of excess oxygen have been carried out by using different catalysts as the cathode material (Hibino, 2000a, 2000b; Marwood \& Vayenas, 1997; Nakatani et al., 1996; Walsh \& Fedkiw, 1997). Walsh (Walsh \& Fedkiw, 1997) proposed substitute dense Pt electrodes to the porous platinum and to use a mixture of ionic $(\mathrm{CeO})$ and electronic $(\mathrm{Pt})$ conductors as a porous cathode. It is well known that substitution of dense electrode to the porous should increase gas penetration to the tpb on the surface of the YSZ-disc solid electrolyte and using of the mixture of ionic $(\mathrm{CeO})$ and electronic $(\mathrm{Pt})$ conductors should lead to the increase of the $t p b$ surface area inside the cathode. As the result both oxygen and nitrogen oxide decomposition take place in such cells and for effective NO adsorption and decomposition the $t p b$ should be free from the adsorbed oxygen. This conclusion agrees well with a fact that the NO decomposes after the oxygen pumping is completed.

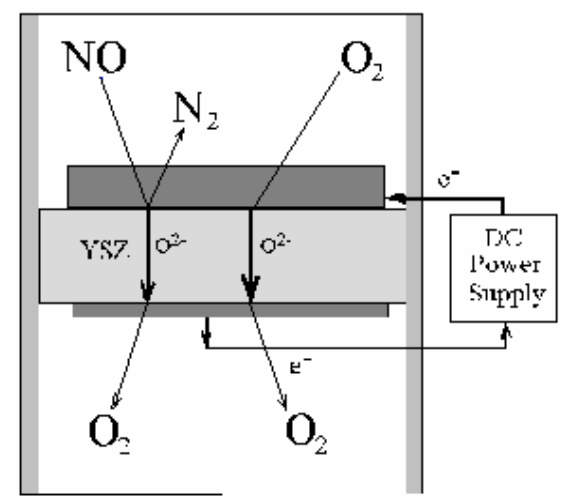

Fig. 1. Conceptual representation of the electrochemical cell for NO decomposition.

To improve the selectivity for NO gas adsorption and decomposition in the presence of the oxygen excess K. Iwayama (Iwayama \& Wang, 1998; Washman et al., 2000) proposed to coat $\mathrm{Pt}$ cathode by different metals or metal oxide. Decomposition activity was measured on metal oxide/Pd(cathode)/YSZ/Pd(anode) at 773-973 K and 3.0V of applied voltage in a flow of $50 \mathrm{ml} / \mathrm{min}$ containing $1000 \mathrm{ppm}$ of $\mathrm{NO}$ and $6 \%$ of $\mathrm{O}_{2}$ in helium. Coating of various metal oxides onto the cathode electrode greatly changed the decomposition activity; the order was $\mathrm{RuO}_{2}>>\mathrm{Pt}>\mathrm{Rh}_{2} \mathrm{O}_{3}>\mathrm{Ni}>$ none $>\mathrm{Ag}>\mathrm{WO}_{3}$. The activity of the system modified by $\mathrm{RuO}_{2}$ has been investigated as a function of the kind of electrode, the applied voltage, and 
the reaction temperature. The cell of $\mathrm{RuO}_{2} / \mathrm{Ag}$ (cathode)/YSZ/Pd(anode) was found to show the most excellent activity among the cells examined.

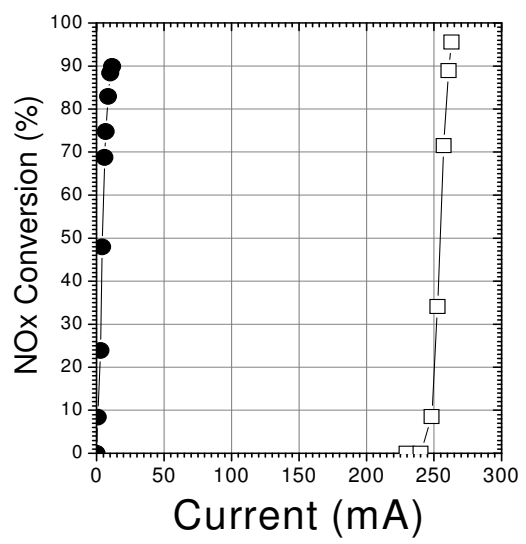

Fig. 2. Dependence of NO conversion on the value of the current passing through the two

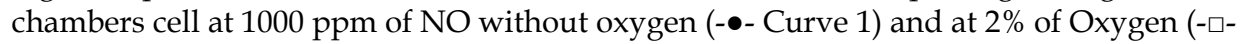
Curve 2) in He (the balance) at gas flow rate $50 \mathrm{ml} / \mathrm{min}$.

Later (Hwang et al., 2001; Matsuda et al., 2001; Washman et al., 2000) a series $\mathrm{La}_{1-x} \mathrm{~A}_{x} \mathrm{BO}_{3}$ perovskite were prepared and systematically evaluated for substitution of the $\mathrm{Pt}$ or $\mathrm{Pd}$ electrodes. A major target of all these researches was the promotion of NO reduction by $\mathrm{F}-$ center type defects in the YSZ surface or inside perovskite type cathodes (Hwang et al., 2001; Matsuda et al., 2001; Washman et al., 2000).

An important characteristic of the efficiency of electrochemical cell is the value of the current efficiency coefficient $(\eta)$. Current efficiency $(\eta)$ can be defined from the value of the oxygen ionic current ( $\mathrm{I}_{\mathrm{NO}}$ ) due to the oxygen from decomposed $\mathrm{NO}$ gas (see eq.2) and a total ionic current flux through the cell $\left(\mathrm{I}=\mathrm{I}_{\mathrm{NO}}+\mathrm{I}_{\mathrm{O} 2}\right)$ as:

$$
\eta=\mathrm{I}_{\mathrm{NO}} /\left(\mathrm{I}_{\mathrm{NO}}+\mathrm{I}_{\mathrm{O} 2}\right)
$$

As illustration current efficiency for $\mathrm{NO}$ decomposition against current is plotted in Fig.3 for LSC | YSZ |Pt and LSCP | YSZ | Pt cells (Hwang et al., 2001). It is seen that relatively high value of current efficiency, ca. 1.5\% can be obtained between 300 and $350 \mathrm{~mA}$. This result shows that the unwanted reaction (Eq. (3)) of oxygen gas adsorption and decomposition fare exceed the desirable reaction of $\mathrm{NO}$ gas adsorption and decomposition.

In 2007 Simonsen et al. (Simonsen et al., 2007) studied spinels with composition $\mathrm{CoFe}_{2} \mathrm{O}_{4}$, $\mathrm{NiFe}_{2} \mathrm{O}_{4}, \mathrm{CuFe}_{2} \mathrm{O}_{4}$, and $\mathrm{Co}_{3} \mathrm{O}_{4}$ as electro-catalyst for the electrochemical reduction of nitric oxide in the presence of oxygen. It was shown that spinels are active for the reduction of both nitric oxide and oxygen. The composition $\mathrm{CuFe}_{2} \mathrm{O}_{4}$ shows the highest activity for the reduction of nitric oxide relative to the reduction of oxygen. However now information was given on the characteristics of the electrochemical cells based on these cathode materials.

K. Kammer (Kammer, 2005) reviewed the investigations in the field of electrochemical reduction of nitric oxide. He has shown that the electrochemical reduction of nitric oxide in 


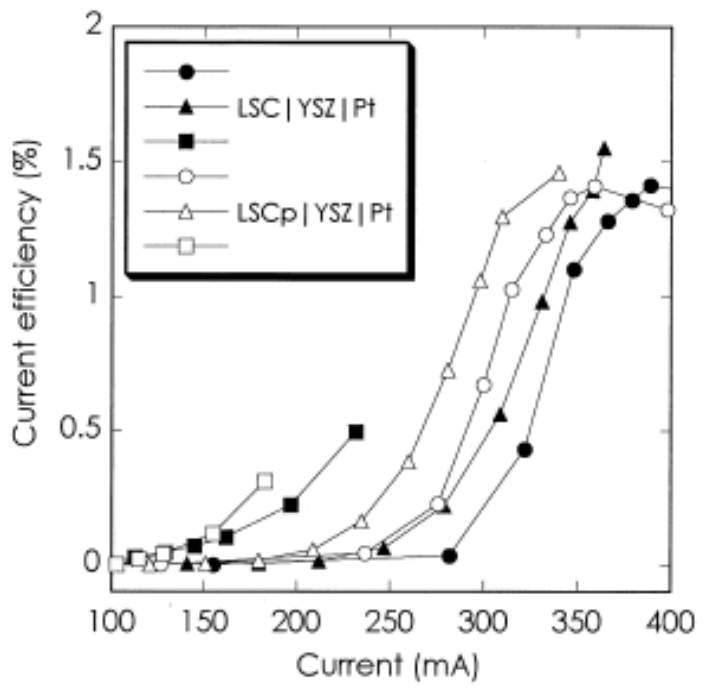

Fig. 3. Current efficiency vs. current curves of LSC u YSZ u Pt and LSPC u YSZ u Pt

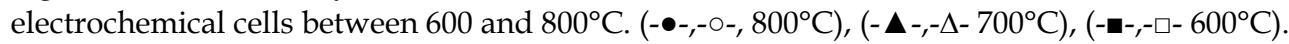

several types of all solid-state electrochemical cells is possible, and proposed, that in order to reduce nitric oxide in an atmosphere containing excess oxygen further development of cathode materials are needed.

In accordance with above we can conclude that all known cathode materials used up now for electrochemical reduction of nitric oxide show a low selectivity for NO reduction in the presence of the excess oxygen and can't be used for practical application.

\section{Electrochemical reactors with multi-layer functional electrode}

To solve the problem of effective electrochemical reduction of nitric oxide in the presence of the excess oxygen S.Bredikhin et al. (Awano et al., 2004; Bredikhin et al., 2001a, 2001b) proposed the concept of artificially designed multilayer structure which should operate as an electrode with high selectivity. At present time a new type of electrochemical reactor with a functional multi-layer electrode has been successfully designed in National Institute of Advanced Industrial Science and Technology (AIST), Nagoya, Japan (Awano et al., 2004; Bredikhin et al., 2004). The typical values of current efficiency in such electrochemical reactors are of the order of $10 \%-20 \%$ at gas composition: $1000 \mathrm{ppm} \mathrm{NO}$ and $2 \% \mathrm{O}_{2}$ balanced in $\mathrm{He}$ and at gas flow rate $50 \mathrm{ml} / \mathrm{min}$. The value of current efficiency depends on the functional multi-layer electrode composition, structure and operating temperature. Such electrochemical reactors show the value of NO selectivity $\left(v_{\text {sel }}\right)$ with respect to oxygen gas molecules $v_{\text {sel }}>5$. This means that the probability for NO gas molecules to be adsorbed and decomposed is at least 5 times higher than for oxygen gas molecules.

The arrangement of the electrochemical reactor with a functional multi-layer electrode is

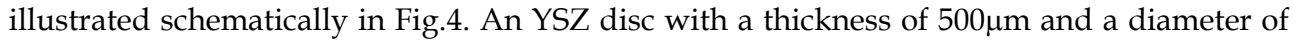


$20 \mathrm{~mm}$ was used as the solid electrolyte. The composite Pt(55vol\%)-YSZ(45vol\%) paste was screen-printed with an area of $1.77 \mathrm{~cm}^{2}$ on one surface of the YSZ disk as the cathode, and then calcined at $1673 \mathrm{~K}$ for 1 hour, to produce a dense Pt(55vol\%)-YSZ(45vol\%) composite with a thickness of about $3 \mu \mathrm{m}$ and diameter of $15 \mathrm{~mm}$ (Bredikhin et al., 2004). A dense Pt collector was connected with a cathode. The NiO-YSZ paste was screen-printed with an area of $2 \mathrm{~cm}^{2}$ over the cathode and sintered at $1773 \mathrm{~K}$ for 4 hours to produce a nano-porous NiOYSZ electro-catalytic electrode with a diameter of $16 \mathrm{~mm}$ and a thickness of about 5-6 $\mu \mathrm{m}$ (Aronin et al., 2005; Awano et al., 2004a; Bredikhin et al., 2006; Hiramatsu, 2004). The nanoporous YSZ layer with a thickness of about $2 \mu \mathrm{m}$ was deposited over the electro-catalytic electrode as a covering layer (Awano et al., 2004b). The commercial TR-7070 (Pt-YSZ) paste was screen-printed with an area of $1.77 \mathrm{~cm}^{2}$ on to the other surface of the YSZ disk as the anode, and then calcined at $1473 \mathrm{~K}$ for 1 hour. Platinum mesh and wire were attached to the cathode and the anode, for connection with the power supply unit.

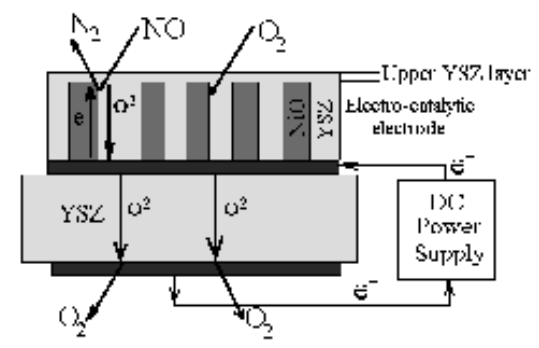

Fig. 4. Conceptual representation of the electrochemical cell with multilayer electro-catalytic electrode.

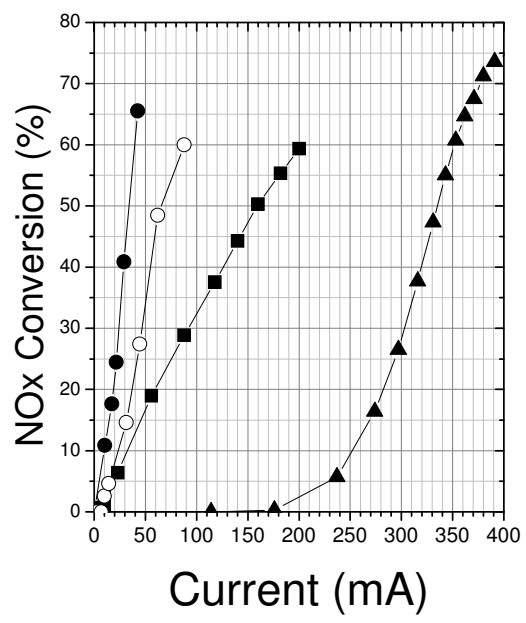

Fig. 5. The dependence of NO conversion on the value of the current for electrochemical reactors with functional multi-layer electrodes (- - $2 \%$ and $-0-10 \%$ of oxygen) and for a reactor with a monolayer electro-catalytic electrode (-m- $2 \%$ of oxygen) and a traditional type of electrochemical cell with Pt-YSZ types of cathode (- $\mathbf{\Delta}-2 \%$ of oxygen). 
The electrochemical reactor was set in a quartz house and connected to a potensio galvanostat (SI1267 and 1255B, SOLARTRON). The applied voltage and current dependence of NO decomposition behavior was investigated. The range of the applied voltage to the electrochemical cell was from 0 to $3 \mathrm{~V}$. The electrochemical decomposition of $\mathrm{NO}$ was carried out at $573-873 \mathrm{~K}$ by passing a mixed gas of $500-1000 \mathrm{ppm}$ of $\mathrm{NO}$ and $2-10 \%$ of $\mathrm{O}_{2}$ in $\mathrm{He}$ (balance) at a flow rate $v=50 \mathrm{ml} / \mathrm{min}$. The concentrations of $\mathrm{NO}$ and of $\mathrm{N}_{2}$ in the outlet gas ([NO $\left.]_{\text {out }}\right)$ were monitored using an on-line $\mathrm{NOx}\left(\mathrm{NO}, \mathrm{NO}_{2}\right.$ and $\left.\mathrm{N}_{2} \mathrm{O}\right)$ gas analyser (Best Instruments BCL-100uH, BCU-100uH) and a gas chromatograph (CHROMPACK Micro-GC CP 2002), respectively.

S. Bredikhin et al. (Awano et al., 2004b; Bredikhin et al., 2004; Hiramatsu et al., 2004) and K. Hamamoto et al. (Hamamoto et al., 2006, 2007) have shown that electrochemical reactors with multi-layer electro-catalytic electrode effectively operate even at low concentration of NOx (300-500ppm) and at the high concentration of oxygen (10\%). From Fig.5 it is seen that the efficiency of NO decomposition by electrochemical reactors with the functional multi-layer electrode far exceeds the efficiency of the traditional type of electrochemical cells.

\section{Microstructure and properties of functional layers of multi-layer electrode}

The electrochemical reactors for selective NOx decomposition can be represented by the following reactor arrangements:

$$
\begin{aligned}
& \text { (Covering layer | Electro-catalytic electrode |Cathode) IYSZ| (Anode) } \\
& \text { (Covering layer | Cathode | Electro-catalytic electrode) IYSZI (Anode) }
\end{aligned}
$$

Let us consider in detail the arrangement of the electrochemical reactor with a functional multi-layer electrode and the properties of each functional layer. The cross-section view of the functional multi-layer electrode is shown in Fig.6.

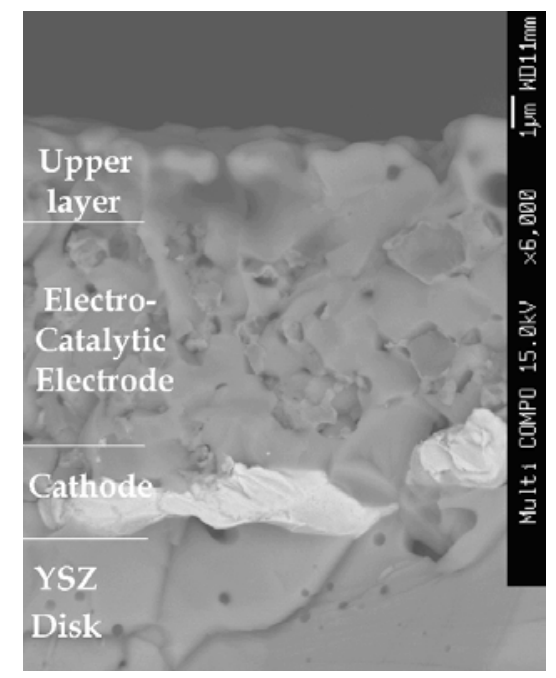

Fig. 6. The cross-section view of the multi-layer electro-catalytic electrode. 
The cathode is a dense $\mathrm{Pt}(55 \mathrm{vol} \%)-\mathrm{YSZ}(45 \mathrm{vol} \%)$ composite with a thickness of about 2-3 $\mu \mathrm{m}$. The nano- porous NiO-YSZ electro-catalytic electrode with a thickness of about 6-8 $\mu \mathrm{m}$ was deposited over the cathode. The porous YSZ layer with a thickness of about 2-3 $\mu \mathrm{m}$ was deposited over the cathode. It is seen that the multi-layer electrode consists from three main functional layers: 1 . Cathode; 2 . Electro-catalytic electrode; 3. Covering layer.

\subsection{Microstructure and the properties of composite cathode}

The external voltage in the electrochemical reactor with a functional multi-layer electrode is applied between the cathode and anode. This voltage leads to the polarization of the YSZdisk and to the generation of a high concentration of oxygen vacancies in the near cathode region (Fig. 4). Due to the gradient in the concentration of the oxygen ions between the nearcathode region of the YSZ disk and the electro-catalytic electrode, diffusion of oxygen ions from the electro-catalytic electrode to the YSZ disk takes place. Since the oxygen ions are a charged species, their diffusion from the electro-catalytic electrode to the YSZ disk leads to an equal flux of electrons from the cathode to the electro-catalytic electrode (Aronin et al., 2005; Awano et al., 2004a; Bredikhin et al., 2006; Hiramatsu, 2004). As a result of electroneutrality, a decrease in the flux of the electrons should lead to the same decrease in the flux of the oxygen ions and the diffusion of oxygen ions should be stopped when the transport of electrons is blocked. In accordance with this consideration we can conclude that for effective reactor operation the cathode should be an electronic and oxygen ionic current conductor with high electronic conductivity along the cathode plane and high oxygen ionic conductivity from the electro-catalytic electrode through the cathode to the YSZ solid electrolyte (Awano et al., 2004b).

In 2004 S.Bredikhin et al. (Bredikhin et al., 2004) studied the correlation between the efficiency of NO decomposition by electrochemical cells with electro-catalytic electrode and the YSZPt cathode compositions. In this study, S.Bredikhin et al. (Bredikhin et al., 2004) examined $\mathrm{YSZ}_{(X)}-\mathrm{Pt}_{(1-X)}$ composite as a cathode for electrochemical cells with a functional multilayer electrode. Electrochemical cells with electro-catalytic electrode and $\mathrm{YSZ}_{(X)}-\mathrm{Pt}_{(1-X)}$ composite cathode with $0,15.0,24.8,35.2,45.4,49.9,55.0$, and 64 vol. \% of YSZ were obtained. Investigation of the current-voltage $(I-V)$ characteristics of the electrochemical cells with multilayer electrode has shown a strong dependence on the composition of the YSZ-Pt cathode (Bredikhin et al., 2004). The best performance was observed for electrochemical cells with YSZ volume contents slightly lower than $50 \mathrm{vol} \%$. To investigate this behavior in detail the value of the current has been plotted as a function of the volume content of YSZ in the YSZ-Pt composite cathode for different values of the electrochemical cell operating voltage. These experimental data are shown in Fig. 7. From this figure, it is seen that an increase of the YSZ content from 0 to $49.9 \%$ leads to a four to five times increase in the value of the current through the cell at the same value of the cell operating voltage. At the same time a small change in the composition of the YSZ-Pt cathode by increasing the YSZ content to more than $50 \mathrm{vol} \%$ leads to an abrupt decrease in the value of the current passed through the cells (Fig. 7) and at $55 \mathrm{vol} \%$ of YSZ current higher than $1 \mathrm{~mA}$ cannot be passed even at applied voltages to the cells of more than $3 \mathrm{~V}$. To describe these phenomena let us consider the processes of electronic and ionic transport through the composite YSZ-Pt cathode. The geometry of the employed electrochemical cell means that electronic transport take place along the cathode through the network of Pt particles and from the cathode through the three-dimensional network of pathways from $\mathrm{NiO}$ or $\mathrm{Ni}$ particles to three-phase boundary 
(TPB) on the surface of the pores inside the electro-catalytic electrode. Oxygen ionic transport takes place perpendicular to the YSZ-Pt cathode plane from the electro-catalytic electrode through the network of YSZ particles to the YSZ disk.

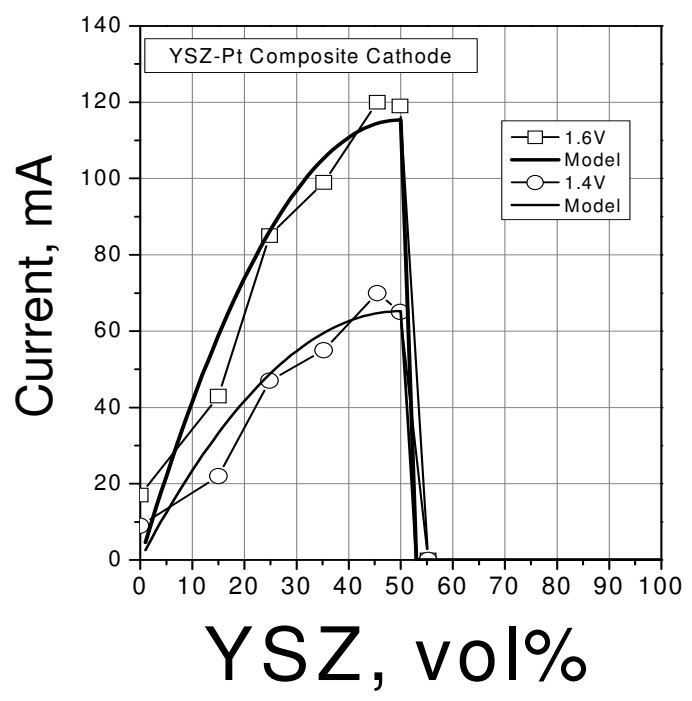

Fig. 7. The experimental dependence of the current on the volume fraction of YSZ in the YSZ-Pt cathode for applied voltages of 1.4 Volts and 1.6 Volts, and comparison with calculated dependencies.

Figure 8 shows the cross-sectional view of the electrochemical cells for different YSZ-Pt cathode compositions. It is seen that the addition of YSZ particles to the cathode leads to the formation of oxygen-conducting YSZ bridges through the electronically conducting $\mathrm{Pt}$ cathode and that the number of such bridges increases with an increasing amount of YSZ in the cathode. From Fig. 8 it is seen that the average size of the electronically insulating (YSZ) particles and electronically conducting $(\mathrm{Pt})$ particles are of the order of 2-3 $\mathrm{mm}$ and are the same as the thickness of the cathode layers. These observations give us the possibility to conclude that the YSZ-Pt cathode is a quasi two-dimensional system and that the twodimensional percolation model can be used to describe the electronic conductivity along the plane of the YSZ-Pt cathode. In accordance with this model a sharp transition in electronic conductivity along the cathode should be observed at $50 \mathrm{vol} \%$ of the electronically conducting Pt phase (Bredikhin et al., 2004). This means that the electronically conducting Pt phase is continuous when the volume fraction of the electronically insulating YSZ phase is less than $50 \mathrm{vol} \%$ and the Pt phase becomes disconnected when the volume fraction of insulating YSZ phase is greater that $50 \mathrm{vol} \%$. This two-dimensional percolation model prediction is in good agreement with the experimentally observed sharp threshold of the value of the current through the electrochemical cell as a function of the volume content of YSZ in the YSZ-Pt composite cathode (Fig. 7) (Bredikhin et al., 2004). 

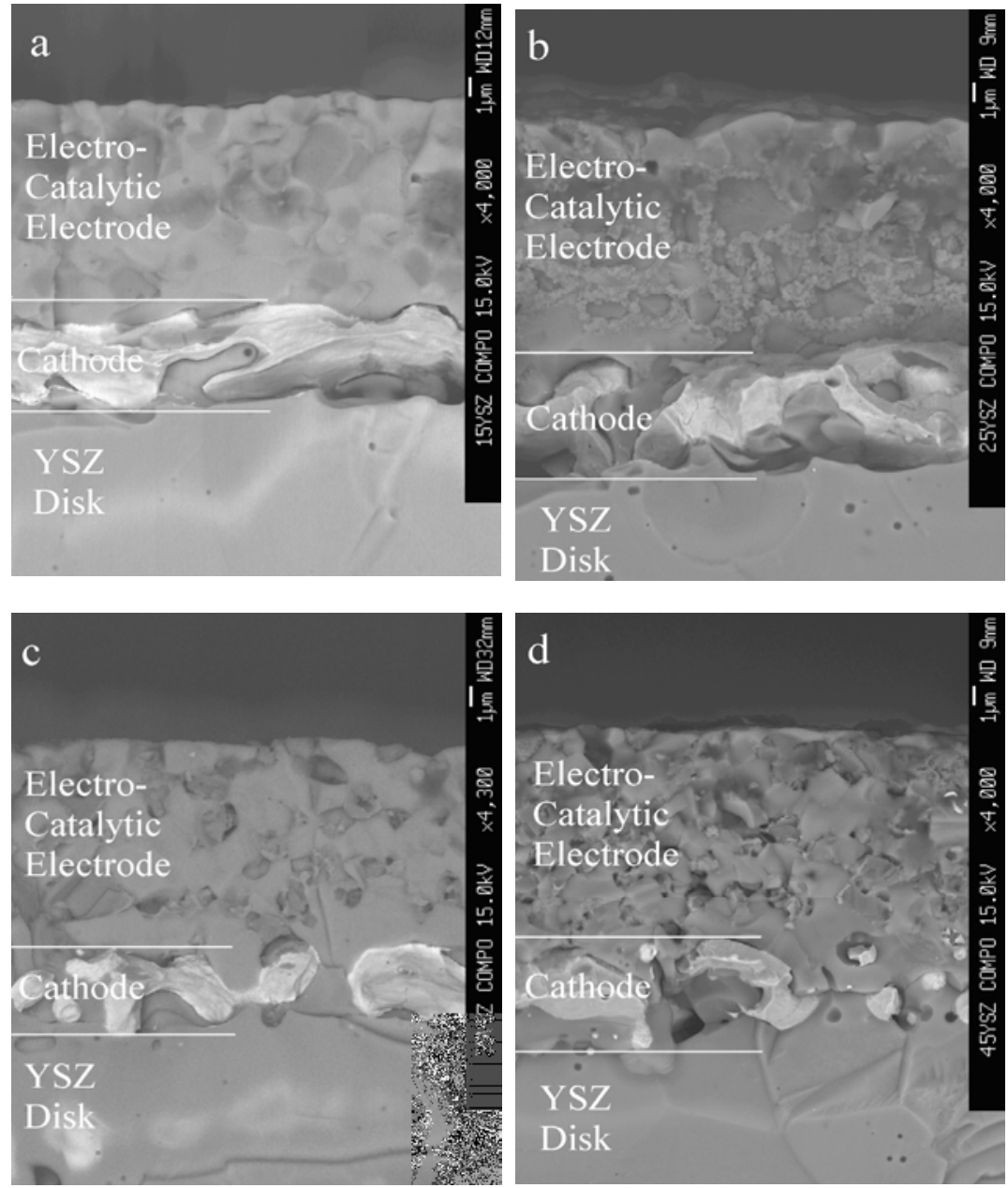

Fig. 8. SEM images of the cross-section of the multi-layer cells with different YSZ-Pt cathode compositions ( $\mathrm{a}-15 \mathrm{vol} \%$ of $Y S Z, b-25 \mathrm{vol} \%$ of $Y S Z, c-35 \mathrm{vol} \%$ of $Y S Z, d-45 \mathrm{vol} \%$ of $Y S Z$ ).

As follows from Figs. 7 and 8 an increase of the YSZ content leads to an increase in the oxygen ionic current through the cell at a given value of the applied external voltage. At the same time when the YSZ content exceeds the percolation threshold (50 vol \%) the Pt phase becomes disconnected, and the flux of electrons from the cathode to the electro-catalytic electrode is blocked. As a result the oxygen ionic diffusion from the electro-catalytic electrode to the YSZ-disk is stopped. In accordance with the above results it is seen that the most critical place for oxygen ion diffusion from the electro-catalytic electrode to the YSZdisk is the oxygen transport through the composite YSZ-Pt cathode, and that compositions with a volume fraction of YSZ slightly lower than the two-dimensional percolation threshold $(1 / 2)$ should have the highest efficiency for charge transport through the electrochemical cell (Bredikhin et al., 2004). 


\subsection{Electro-catalytic electrode}

a. Peculiarity of ambipolar conductivity of the electro-catalytic electrode

The external voltage $\left(\mathrm{V}_{0}\right)$ in the electrochemical reactor is applied between the cathode and the anode (Fig. 4$)$, and the voltage drop is equal to the sum of the polarizing voltage $\left(\mathrm{V}_{\mathrm{pol}}\right)$ and to the Ohms voltage $\left(\mathrm{V}_{\mathrm{Ohm}}=\mathrm{R}_{\mathrm{YSZ}} \times \mathrm{I}_{\mathrm{Ox}}\right)$ drop through the YSZ disk

$$
\mathrm{V}_{0}=\mathrm{V}_{\mathrm{pol}}+\mathrm{V}_{\mathrm{Ohm}}=\mathrm{V}_{\mathrm{pol}}+\mathrm{R}_{\mathrm{YSZ}} \times \mathrm{I}_{\mathrm{ox}}
$$

where RYSZ is the resistance of the YSZ disk and $I_{0 x}$ is the value of oxygen ionic current through the cell. The formation of the gradient in the concentration of the oxygen ions in the YSZ disc under the DC polarization voltage $V_{\text {pol }}$ can be described in accordance with the well-known equation (Hamamoto et al., 2007; Kobayashi et al., 2000; Schoonman, as cited in Chowdari \& Radakrishna, 1998; Wagner, as cited in Delahay \& Tobias, 1966)

$$
\mu_{\text {cathode }}=\mu_{\text {anode }}+2 \mathrm{e} \times \mathrm{V}_{\mathrm{pol}}=\mu_{\mathrm{o}}+1 / 2 \mathrm{kT} \ln \left(\mathrm{P}_{\mathrm{O} 2} / \mathrm{P}_{\mathrm{o}}\right)+2 \mathrm{e} \times \mathrm{V}_{\mathrm{pol}},
$$

where $\mu_{o}$ and $P_{o}$ are standard values and where the chemical potential of the oxygen at the surface of the electro-catalytic electrode $\left(\mu_{\mathrm{CE}}\right)$ and in the anode region of YSZ disc ( $\left.\mu_{\text {anode }}\right)$ is fixed by the oxygen gas pressure $\left(\mathrm{P}_{\mathrm{O} 2}\right)\left(\mu_{\mathrm{CE}}=\mu_{\text {anode }}=\mu_{\mathrm{o}}+1 / 2 \mathrm{kT} \ln \left(\mathrm{P}_{\mathrm{O} 2} / \mathrm{P}_{\mathrm{o}}\right)\right)$. Then the difference in the chemical potential between the near cathode region and the surface of the electro-catalytic electrode should result in the Nernst potential formation $(\Delta \phi)$ through the electro-catalytic electrode

$$
\Delta \phi=\mathrm{V}_{\mathrm{pol}}=\left(\mathrm{V}_{0}-\mathrm{R}_{\mathrm{YSZ}} \times \mathrm{I}_{\mathrm{ox}}\right)
$$

The value of the oxygen ionic current through the electro-catalytic electrode depends on the value of the Nernst potential and on the value of the electro-catalytic electrode ambipolar conductivity $\left(\sigma_{\mathrm{amb}}\right)$ as

$$
\mathrm{I}_{\mathrm{ox}}=\Delta \phi \times \sigma_{\mathrm{amb}}
$$

As follows from equations (8) and (9) the value of ionic current through the electrochemical cell depends on the value of ambipolar conductivity of electro-catalytic electrode $\left(\sigma_{\mathrm{amb}}\right)$ and on the value of oxygen ionic conductivity (RYSZ) of YSZ disc as

$$
\mathrm{I}_{\mathrm{ox}}=\left(\mathrm{V}_{0} \times \sigma_{\mathrm{amb}}\right) /\left(1+\mathrm{R}_{\mathrm{YSZ}} \times \sigma_{\mathrm{amb}}\right) .
$$

It is seen that when $\mathrm{R}_{\mathrm{YSZ}} \times \sigma_{\mathrm{amb}}<1$, there is a linear dependence between ionic current through the cell and the value of ambipolar conductivity

$$
\mathrm{I}_{\mathrm{ox}} \approx\left(\mathrm{V}_{0} \times \sigma_{\mathrm{amb}}\right) \text {. }
$$

In the year 2001 S.Bredikhin et al. (Bredikhin et al., 2001a, 2001b, 2001c) have shown that for electrochemical cells with nano-porous electro-catalytic electrode there is a linear dependence between the value of NO conversion $(\Delta \mathrm{NO})$ and value of oxygen ionic current passed through the cell

$$
\Delta \mathrm{NO}=(1 /(\mathrm{F} \times v \times n)) \times \eta \times \mathrm{I}_{\mathrm{ox}},
$$


where $\mathrm{n}=2$ is the charge of the oxygen ions, F- is a Faraday constant, $v$ is a total gas flow rate and $\eta$ is current efficiency. From equations (11) and (12) it is follows that the rate of NO decomposition depends on the external voltage applied to the cell and on the value of ambipolar conductivity as

$$
\Delta \mathrm{NO}=(1 /(\mathrm{F} \times v \times \mathrm{n})) \times \eta \times \mathrm{V}_{0} \times \sigma_{\mathrm{amb}}
$$

It is obvious that for optimization of the electrochemical cell for $\mathrm{NO}$ decomposition it is necessary to design the cell with the highest value of the ambipolar conductivity. To analyze the specific features of the ambipolar conductivity of the NiO-YSZ composite electrode the calculated value of $\sigma_{\mathrm{amb}}$ (see Eq.11) has been plotted as a function of the volume content of $\mathrm{NiO}$ in the NiO-YSZ composite electrode. These data are shown in Fig.9.

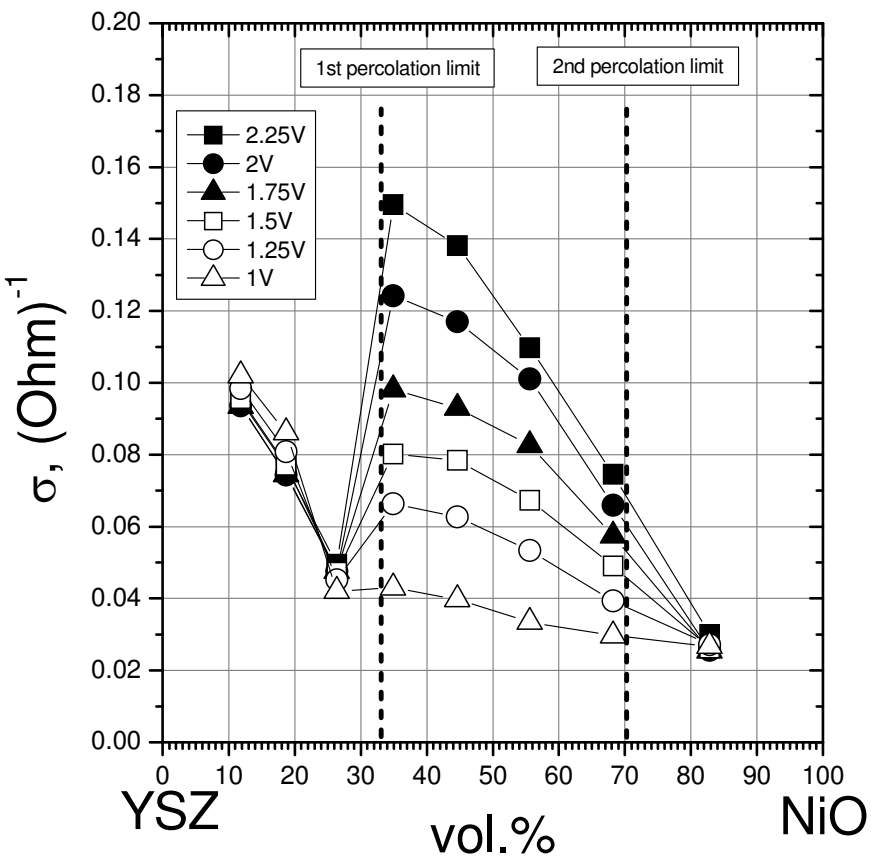

Fig. 9. The dependence of the value of the ambipolar conductivity on the volume fraction of $\mathrm{NiO}$ in Ni-YSZ electro-catalytic electrode

It is seen that when the external voltage is higher than 1.5 volt, the two percolation transitions of electronic and ionic conductivities lead to a composition range from $1 / 3$ to $2 / 3$, in which the ambipolar conductivity is much higher than those in the other regions. This suggests that in order to achieve high value of ambipolar conductivity, the volume fractions of each phase have to be within $1 / 3 \sim 2 / 3$ and external voltage should be higher then 1.5 volt. It should be noted that in the composition range from $1 / 3$ to $2 / 3$ the value of ambipolar conductivity increases with increasing of the voltage applied to the cell. As an illustration Fig.10 shows the dependence of the value of the ambipolar conductivity on the voltage for two NiO-YSZ composite electrodes with $\mathrm{NiO}$ volume content $82.5 \%$ and $35 \%$. 


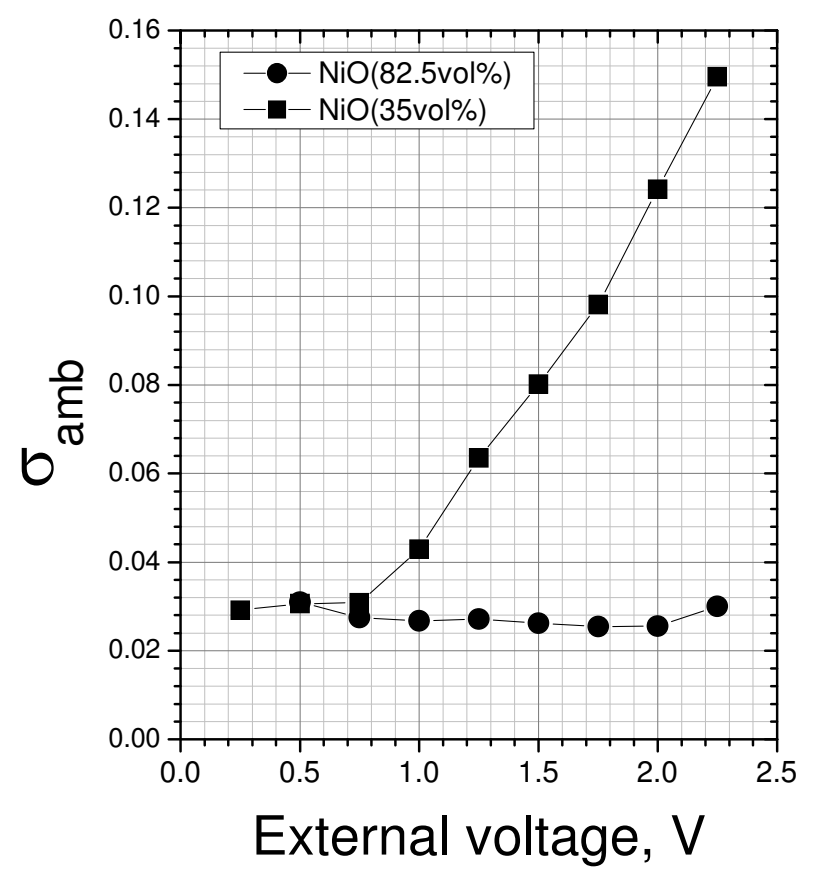

Fig. 10. The dependence of the value of the ambipolar conductivity on the cell operating voltage for two NiO-YSZ composite electrodes with $\mathrm{NiO}$ volume content $82.5 \%$ and $35 \%$.

From Figs. 9 and 10 it is seen that for the composition range from $1 / 3$ to $2 / 3$ the application of external voltage leads to 6-10 times increase of the value of ambipolar conductivity. Such unusual dependence of the value of conductivity on the applied voltage shows that change of the chemical composition of NiO-YSZ electro-catalytic electrode takes place under the cell operation.

b. Reduction-oxidation processes and the structure of the electro-catalytic electrode

The distinguishing feature of such reactors is the artificial nano-structure formed in the $\mathrm{NiO} / \mathrm{YSZ}$ interface of the electro-catalytic electrode under operation. The essential changes occur in the interfacial boundary region between $\mathrm{NiO}$ and YSZ grains. After the electrochemical cell operation for 22 hours at a cell voltage lower than 2.2 Volts they are as follows (Aronin et al., 2005).

1. New grains nucleate and grow in the pore zone of $\mathrm{NiO}$ near-boundary regions. The zone of new grains spreads into the depth of the $\mathrm{NiO}$ grain (Fig. 11). In some cases this zone of new grains devours "old" NiO grain completely (Figs. 12a and 12b). The electron diffraction patterns from these regions contain ring reflections of $\mathrm{Ni}$ in addition to $\mathrm{NiO}$ reflections (Aronin et al., 2005). The size of $\mathrm{Ni}$ grains is $5-20 \mathrm{~nm}$ and they are seen in the dark field electron microscopy image (Fig. 12b). This image was obtained in the reflection marked by the arrow in the electron diffraction pattern (Fig. 12a, insert). The new grains are both $\mathrm{Ni}$ and $\mathrm{NiO}$ phases. 


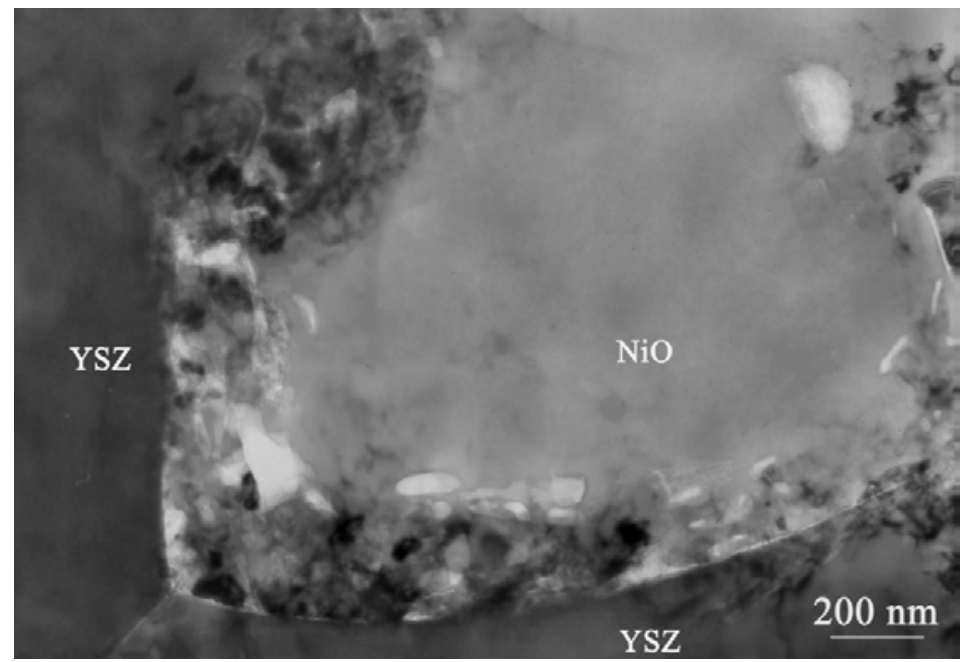

Fig. 11. Interfacial boundary between YSZ and NiO grains of the sample after cell operation.
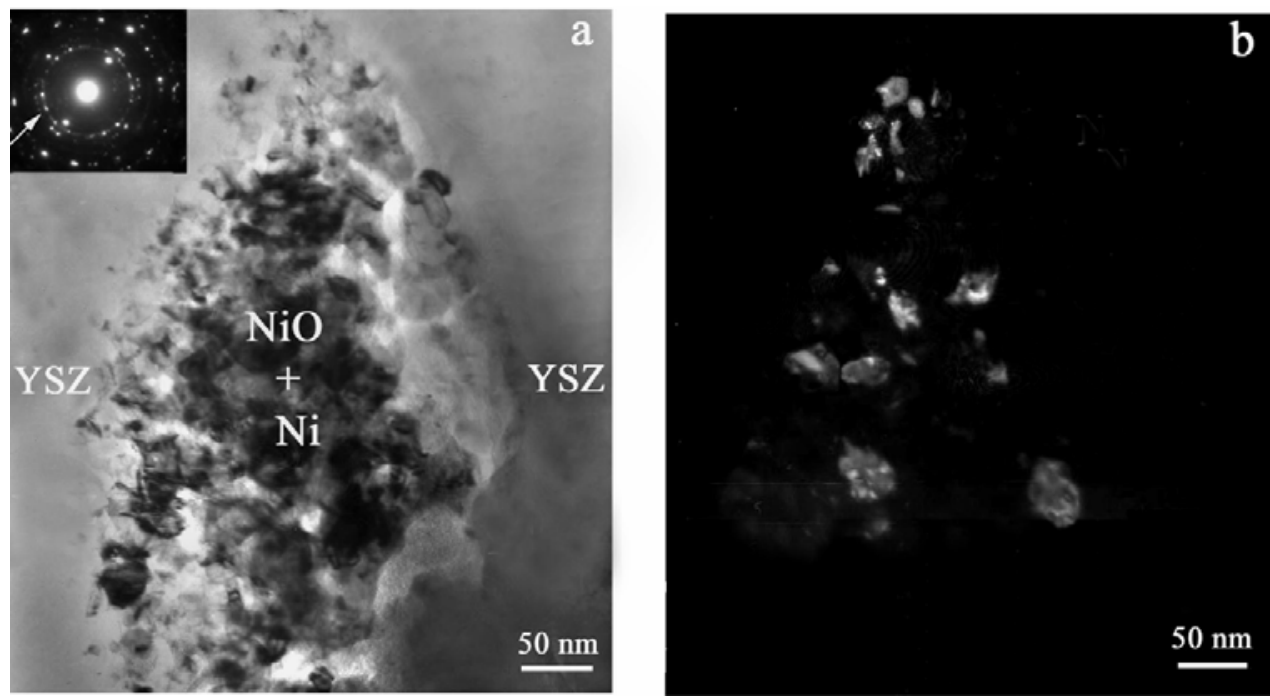

Fig. 12. Bright field TEM image (a) and dark field TEM images (b) of new NiO and Ni grains zone devoured "old" NiO grain.

2. In the region with new $\mathrm{NiO}$ grains the pores are located both in the interfacial vicinity and before the front of new growing grains. Sometimes small $\mathrm{NiO}$ grains are surrounded by the pores on all sides. Separate pores are also observed in the region of new grains, located between the new grains (Fig. 11). The high resolution electron microscopy images of the near-boundary region of YSZ grain and small $\mathrm{NiO}$ grain formed during the cell operation at different magnifications are shown in Fig. 13. The size of the new $\mathrm{NiO}$ grains varies from 10 to $100 \mathrm{~nm}$ depending on the location. 


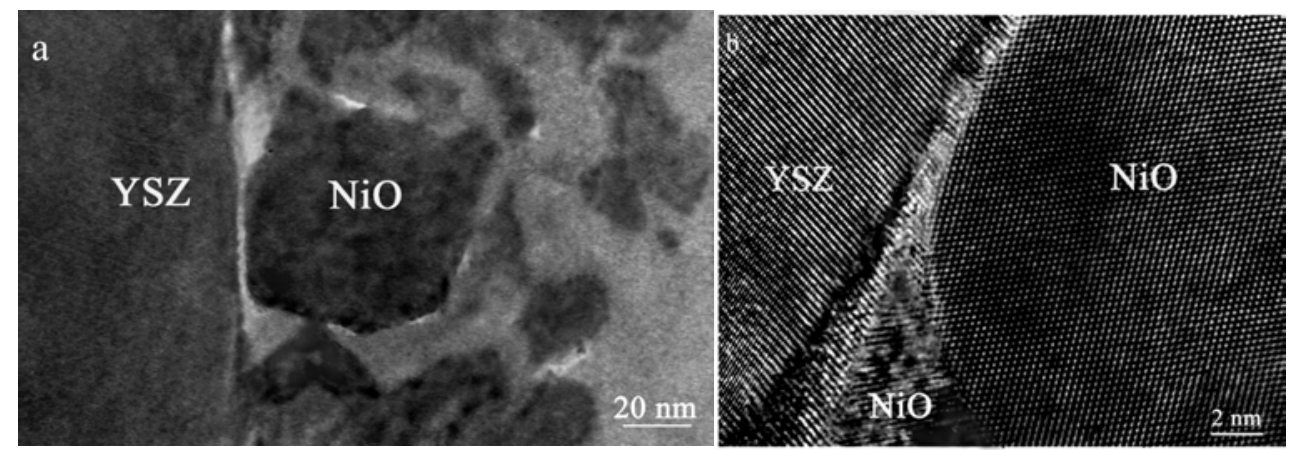

Fig. 13. HREM images of a near-boundary region of an YSZ grain and small NiO grains formed during the cell operation ( $a$ and $b$ different magnification).

3. An orientation relationship has been found to exist between the lattices of YSZ and new $\mathrm{NiO}$ grains:

$$
\text { (310) YsZ }\left\|(110)_{\mathrm{NiO}},[001]_{\mathrm{YSZ}}\right\|[1 \overline{1} 1]_{\mathrm{NiO}}
$$

The presence of the orientation relationship between the lattices of YSZ and NiO grains indicates that the new $\mathrm{NiO}$ grains may nucleate on the YSZ grains as on the substrate and in this case their surface energy will decrease. This result is a direct evidence of the process of oxygen spillover from YSZ to Ni grains even in the presence of oxygen in the surrounding gas.

The distinguishing feature of the microstructure of the YSZ/(Ni-NiO) interface is the 10-50 $\mathrm{nm} \mathrm{Ni}$ grains reversibly produced during the reactor operation. Schematically the microstructure of the $\mathrm{YSZ} / \mathrm{NiO}$ interface reversibly produced during the cell operation is represented in Fig.14. It is well known that adsorption and decomposition of NOx gas molecules occurs in preference to oxygen gas molecules on $\mathrm{Ni}$ grain surfaces (Lindsay et al., 1998; Miura et al., 2001; Rickardsson et al., 1998). In addition, we should mention that rough surfaces and nano-size Ni grains are much more active for breaking of NO chemical bonds than smooth, flat surfaces (Garin, 2001; Lindsay et al., 1998). Based on the above results, the following reaction mechanism was proposed for $\mathrm{NO}$ decomposition on the nano-size $\mathrm{Ni}$ grains produced during the reactor operation.

$$
\begin{gathered}
\mathrm{NO}+\mathrm{Ni} \rightarrow \mathrm{Ni}-\mathrm{NO} \\
2 \mathrm{Ni}-\mathrm{NO} \rightarrow 2 \mathrm{NiO}+\mathrm{N}_{2}
\end{gathered}
$$

$\mathrm{NO}$ gas molecules are first chemisorbed on Ni. As a second step the chemisorbed NO decomposes to form $\mathrm{N}_{2}$, oxidizing $\mathrm{Ni}$ to $\mathrm{NiO}$.

Oxygen ionic current passed though the network of YSZ particles surrounding the Ni grains. This process removed oxygen species from the electrode and permitted the reactions (14) and (15) to reoccur. The regeneration reaction of the reduction of $\mathrm{NiO}$ to $\mathrm{Ni}$ takes place at the $\mathrm{NiO} / \mathrm{YSZ}$ interface under the reactor operation 


$$
\mathrm{NiO}+\mathrm{V}_{\mathrm{O}}\left(\mathrm{ZrO}_{2}\right)+2 \mathrm{e} \rightarrow \mathrm{Ni}+\mathrm{O}^{2-}\left(\mathrm{ZrO}_{2}\right)
$$

Therefore, the reduction of $\mathrm{NiO}$ grains into $\mathrm{Ni}$ grains and the oxidation of $\mathrm{Ni}$ grains into $\mathrm{NiO}$ take place continuously during reactor operation. As a result the catalytic activity for NO decomposition is independent of the operation time.

At the same time oxygen gas molecules have a preference for adsorption by F-type centers on the surface of YSZ.

$$
\mathrm{O}_{2}+4 \mathrm{e}^{-}+2 \mathrm{~V}_{\mathrm{O}}\left(\mathrm{ZrO}_{2}\right) \rightarrow 2 \mathrm{O}^{-}\left(\mathrm{ZrO}_{2}\right)
$$

From this consideration it follows that under the reactor operation adsorption and decomposition of $\mathrm{NO}$ and $\mathrm{O}_{2}$ gas molecules occur on the surface of $\mathrm{Ni}$ grains and by $\mathrm{F}-$ centers on the surface of YSZ grains, respectively. The design of an electrochemicallyassembled electrode with two kinds of active sites provides a way to suppress the unwanted reaction of oxygen gas adsorption (Eq.(17)) and to increase the desirable reaction of NO gas decomposition Eqs.(14,15).

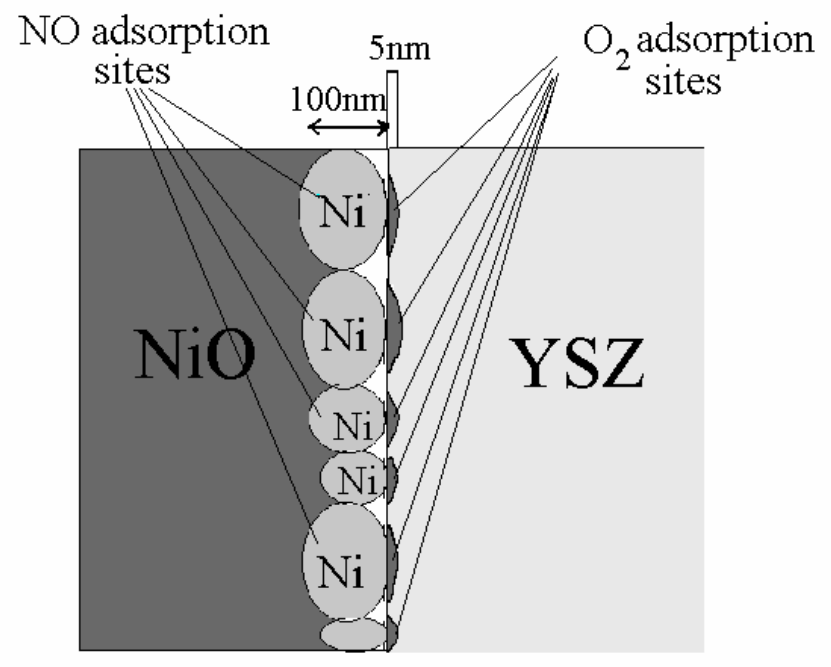

Fig. 14. Schematic representation of the microstructure of the YSZ-NiO interface and of the sites for NO and Oxygen gases adsorption in the self-assembled electro-catalytic electrode.

\subsection{Covering layer}

The deposition of a thin (2-3 nm) covering YSZ layer leads to a suppression of the oxygen adsorption and decomposition. Additionally, the deposition of the covering layer leads to an increase of the amount of nanosize Ni grains located in the near interface boundary porous region between the grains of $\mathrm{NiO}$ and YSZ. As a result, electrochemical reactors with the functional multilayer electrode show much better selectivity for NO gas decomposition even with respect to the electrochemical cells with electro-catalytic electrode but without a covering layer. 
To optimize the characteristics of the electrochemical cells with multi-layer electrode, we have carried out the investigations of rate of NOx decomposition depending of the upper layer microstructure. Our investigations has shown that the best characteristics of the cells for selective NO decomposition can be reached for the electrochemical cells with the thin upper YSZ layer $(2-3 \mu \mathrm{m})$ sintered at temperature $1450^{\circ} \mathrm{C}$.
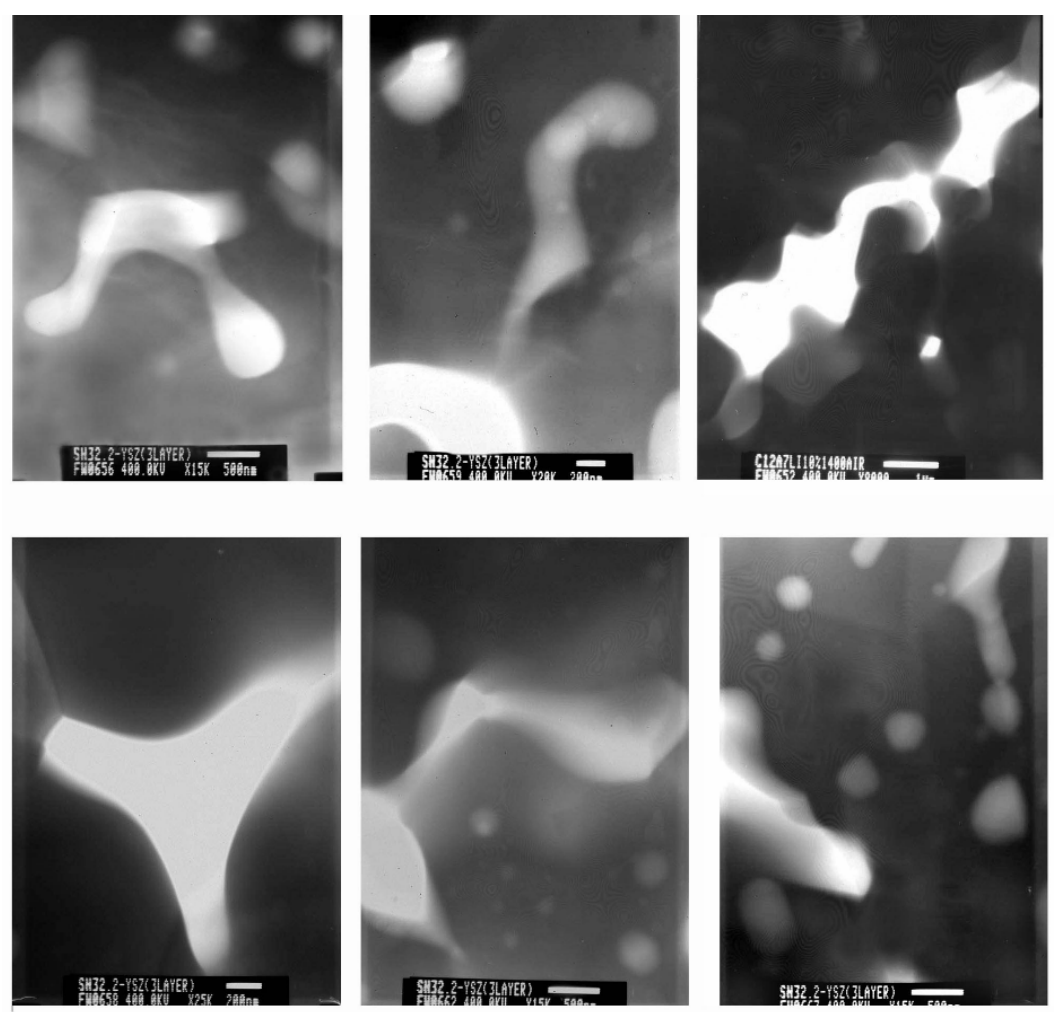

\section{SH 32.2 3-th layer}

Fig. 15. TEM images of the structure of the covering YSZ layer sintered at $1450^{\circ} \mathrm{C}$.

The transmission electron microscopy investigations of the upper layer and of the electrocatalytic electrode were carried out on a JEOL 4000 FX microscope. Foils for the electron microscopy investigations were prepared by mechanical polishing followed by ion milling. The structure of the upper YSZ layer sintered at temperature $1450^{\circ} \mathrm{C}$ is shown in Fig.15. This figure shows some typical microstructures of the upper layer. It is seen that upper layer is porous and that the pores form channels with a size of $200-500 \mathrm{~nm}$, or they have ellipsoidal shape with a size $50-100 \mathrm{~nm}$.

The structure of the electro-catalytic electrode in the electrochemical cell with multi-layer electrode is shown in Fig.16. This figure shows a typical structure of electro-catalytic electrode after the cell operation. Data of chemical composition of this structure obtained by 
EDS method are also displayed in the same figure. From Fig.16 it is seen that the structure consists of $\mathrm{NiO}, \mathrm{Ni}$ and $\mathrm{YSZ}$ grains. The Ni grins are located in the near interface boundary porous region between the grains of $\mathrm{NiO}$ and YSZ. From above consideration it follows that this structure is the same as a structure of the field-quenched electro-catalytic electrode in the cells without upper layer (Aronin et al., 2005; Bredikhin et al, 2006). It is obvious that deposition of the upper layer leads to suppressing of the oxygen gas adsorption and to an increase of the concentration of the oxygen vacancies in the YSZ grains. As the result both the rate of the reduction of the $\mathrm{NiO}$ to $\mathrm{Ni}$ and of the amount of new $\mathrm{Ni}$ grains increase in the YSZ/(Ni-NiO) interface region. Therefore the electrochemical cells with multi-layer electrode should show a much higher selectivity for NOx gas decomposition in the presence of excess oxygen than all known cells.
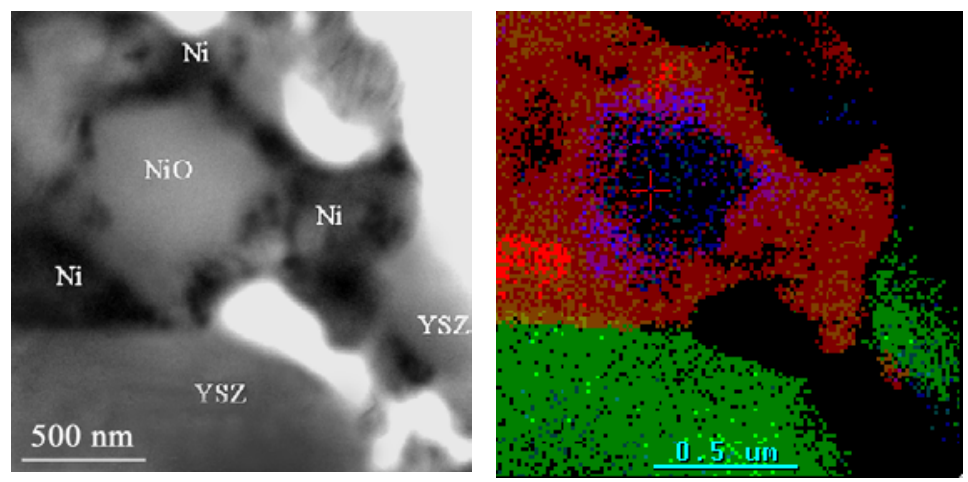

Fig. 16. TEM image of the structure of the electro-catalytic electrode (A) and the chemical composition of this structure obtained by EDS method (B).

One more important advantage of the electrochemical reactor with multi-layer electrode should be discussed. Our investigations have shown that electrochemical cells with multilayer electro-catalytic electrode effectively operate even at low concentration of NOx (300$500 \mathrm{ppm})$ and at the high concentration of oxygen (10\%) in the exhaust gas. In Fig.17 the NO conversion is plotted as a function of the current for one compartment electrochemical cell with multi-layer electrode at different concentration of NO (500 ppm or $1000 \mathrm{ppm}$ ) and oxygen $(2 \%$ or $10 \%)$ at a gas flow rate $50 \mathrm{ml} / \mathrm{min}$ and at temperature $560^{\circ} \mathrm{C}$. From this figure it is seen that the decrease of the NO concentration from $1000 \mathrm{ppm}$ to $500 \mathrm{ppm}$ leads to the two times decrease of the value of the current required for $30 \% \mathrm{NO}$ decomposition for both $2 \%$ and $10 \%$ of oxygen in the gas mixture. Direct proportion between NO concentration in the exhaust gas and the value of the current required for $\mathrm{NO}$ decomposition confirms our proposal that the process of $\mathrm{NO}$ gas adsorption and decomposition is practically independent of the oxygen gas adsorption and decomposition. Additional we should mention that increase of the oxygen content in the investigated gas from $2 \%$ to $10 \%$ at fixed $\mathrm{NO}$ concentration leads to the 1.5 times increase only of the value of the current required for NO decomposition. This result shows that the oxygen adsorption and decomposition in the electrochemical cells with multi-layer electrode is suppressed. In accordance with above we can conclude that new type of electrochemical reactor with multi-layer electro-catalytic electrode can be used for effective NO decomposition even in the presence of high oxygen concentration. 


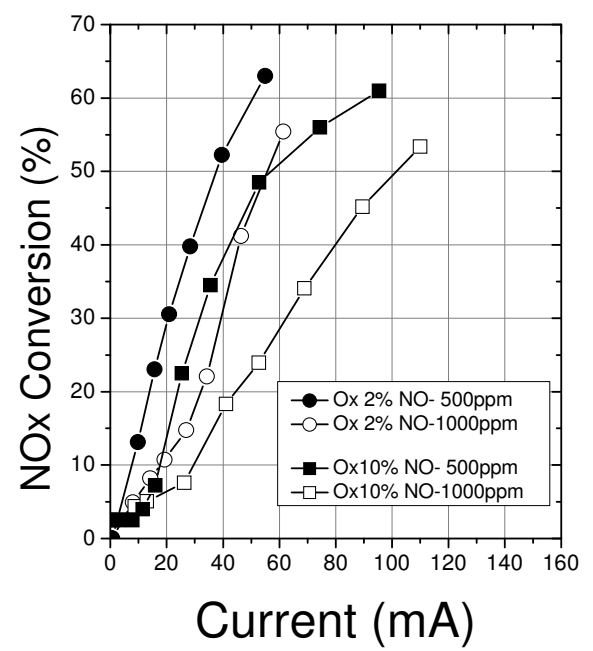

Fig. 17. The dependence of NO conversion on the value of the current for electrochemical cells with multi-layer electro-catalytic electrodes in the presence of $2 \%$ of Oxygen (500 ppm and -O- 1000 ppm of NO gas) and of 10\% of Oxygen (-口- 500 ppm and - $\square-$ 1000ppm of NO gas).

The design of the self-assembled electrode with two kinds of active sites provides a way to suppress the unwanted reaction of oxygen gas adsorption and to increase many times the desirable reaction of NO gas decomposition. For the first time, an electrochemical cell with multi-layer electro-catalytic electrode for selective $\mathrm{NO}$ decomposition in the presence of excess oxygen $(10 \%)$ operating at a low value of electrical power was designed. These results indicate that electrochemical reactors with multi-layer electro-catalytic electrode can be used for practical applications.

\section{Intermediate and low temperature electrochemical reactors with multilayer functional electrode}

In 2006 K.Hamamoto et.al. (Hamamoto et.al., 2006, 2007) proposed to use an electrochemical rector with multilayer functional electrode for intermediate temperature operation. The cell performance represented on $(5 b)$ was used for intermediate temperature operation.

8YSZ (8 mol \% $\mathrm{Y}_{2} \mathrm{O}_{3}$-doped $\left.\mathrm{ZrO}_{2}\right)$, 10YSZ (10 mol \% $\mathrm{Y}_{2} \mathrm{O}_{3}$-doped $\mathrm{ZrO}_{2}$ ) and ScCeSZ $(10 \mathrm{~mol}$ $\% \mathrm{Sc}_{2} \mathrm{O}_{3}$ and $1 \mathrm{~mol} \% \mathrm{CeO}_{2}$-doped $\left.\mathrm{ZrO} 2\right)$ were selected as solid electrolytes. The electrocatalytic electrodes with compositions NiO-8YSZ, NiO-10YSZ and NiO-ScCeSZ (with 55 $\mathrm{mol} \%$ of $\mathrm{NiO}$ ) were deposited on the surface of 8YSZ, 10YSZ and ScCeSZ solid electrolyte disks, respectively. Figure 18 shows the values of current efficiency $(\eta)$ plotted as a function of applied voltage for such electrochemical reactors operated at $475^{\circ} \mathrm{C}$. The value of selectivity $\left(v_{\text {sel }}\right)$ of such reactors for NO gas molecules decomposition is also displayed in Fig. 18 (Hamamoto et.al., 2006). From Fig.18 it is seen that in electrochemical reactors with electro-catalytic electrodes the probability for $\mathrm{NO}$ gas molecules to be adsorbed and decomposed is at least 5 times higher than for oxygen gas molecules. 


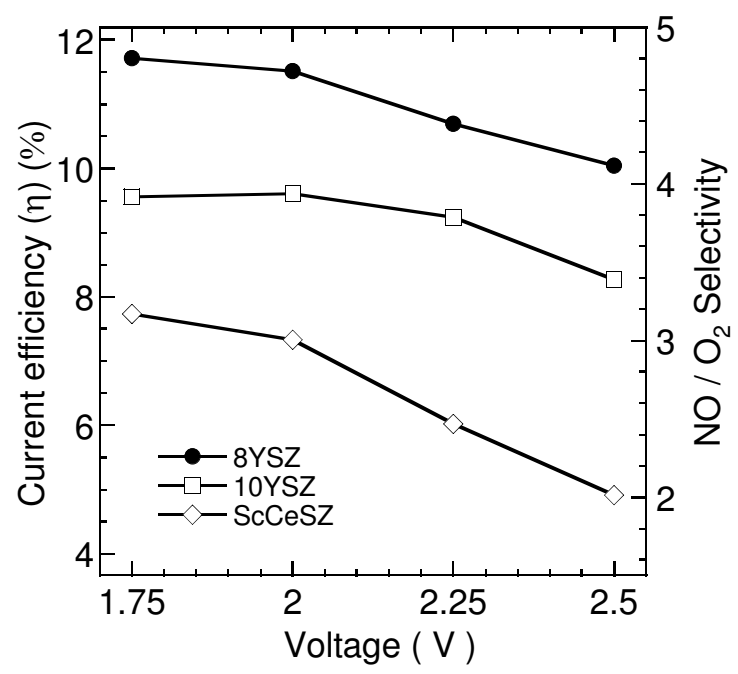

Fig. 18. Dependence of current efficiency for $\mathrm{NO}$ decomposition and $\mathrm{NO} / \mathrm{O}_{2}$ selectivity on operating voltage at $475^{\circ} \mathrm{C}$.

In 2008 K.Hamamoto et.al. (Hamamoto et al., 2008) proposed to use an electrochemical reactor with additional NOx adsorption layer deposited on the top of the multilayer electrocatalytic electrode. Such type of cell can be represented by following cell arrangement:

NOx adsorbent | (Covering layer |Cathode | Electro-catalytic electrode) |YSZ| (Anode)

The authors (Hamamoto et al., 2008) tested three systems which are generally used as NOx adsorber catalyst. The $\mathrm{Pt} / \mathrm{K} / \mathrm{Al} 2 \mathrm{O} 3, \mathrm{Pt} / \mathrm{Na} / \mathrm{Al} 2 \mathrm{O} 3$ and $\mathrm{Pt} / \mathrm{Cs} / \mathrm{Al} 2 \mathrm{O} 3$ adsorbents were prepared from a $\mathrm{Al} 2 \mathrm{O} 3$ (Merck, p.a., specific surface area $=10 \mathrm{~m} 2 \mathrm{~g}-1$ ) support suspension in water, to which a solution containing $\mathrm{KNO} 3$ (NaNO3, CsNO3) and with aqueous solutions of platinum nitrate $(\mathrm{Pt}(\mathrm{NO} 3) 2)$ was added, in order to obtain a load of $10 \mathrm{wt} \%$ of $\mathrm{K}$ $(\mathrm{Na}, \mathrm{Cs})$ and $3 \mathrm{wt} \%$ of Pt. The mixture was heated while being vigorously stirred until a paste was achieved, which was dried in an oven for $24 \mathrm{~h}$ at $200^{\circ} \mathrm{C}$ and crushed and calcined at $600^{\circ} \mathrm{C}$ for $2 \mathrm{~h}$.

To clarify the capability of a NOx adsorption layer on the multilayer cathode, K.Hamamoto et.al. (Hamamoto et al., 2008) carried out the NOx decomposition measurements of the YSZ based cells with and without a NOx adsorbent at a fixed operating voltage, $U=2.5 \mathrm{~V}$, on the cells under various $\mathrm{O} 2$ concentrations at $500^{\circ} \mathrm{C}$ by passing a mixed gas with $1000 \mathrm{ppm}$ of $\mathrm{NO}$ in He through the cell at a gas flow rate of $200 \mathrm{ml} / \mathrm{min}$ (Fig. 19). As a result, NOx adsorption layers have improved the NOX decomposition properties though the current values of each cell were almost the same.

From Fig.19 it is seen that the values of current efficiency $(\eta)$ for electrochemical reactor with the $\mathrm{Pt} / \mathrm{K} / \mathrm{Al} 2 \mathrm{O} 3$ adsorbent are four - five times higher compared with the reactor without adsorbent. The values of current efficiency in such reactors increase up to $20 \%$ and the values of the $\mathrm{NO} / \mathrm{O}_{2}$ selectivity up to 25 (Fig.20). Additionally we should mention that such 
electrochemical reactors effectively decompose $\mathrm{NOx}$ even at low temperature range $\left(<300^{\circ} \mathrm{C}\right)$.

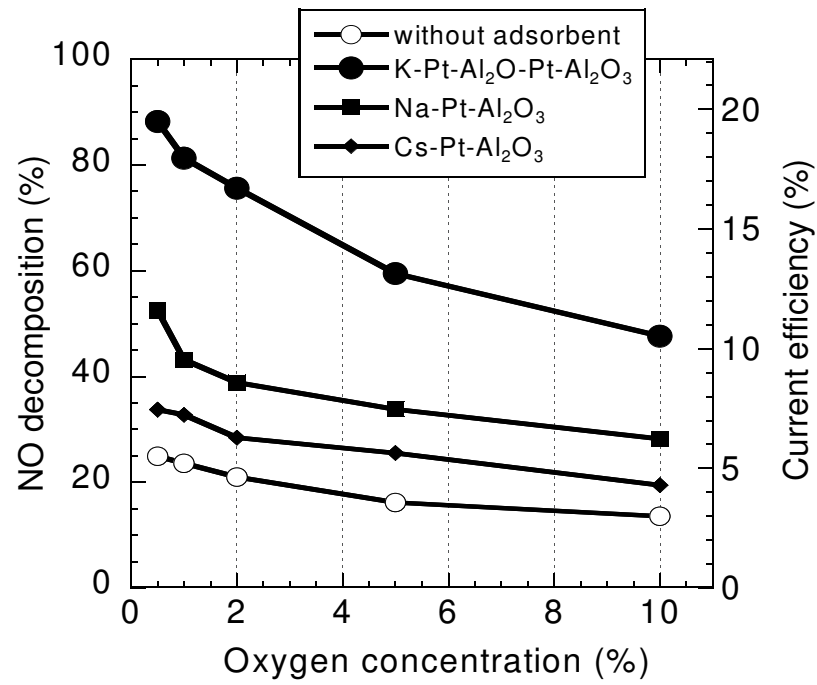

Fig. 19. Dependence of NO decomposition and of the value of current efficiency on the $\mathrm{O}_{2}$ concentrations for the YSZ based electrochemical reactor with and without a NOx adsorbent at $500^{\circ} \mathrm{C}$.

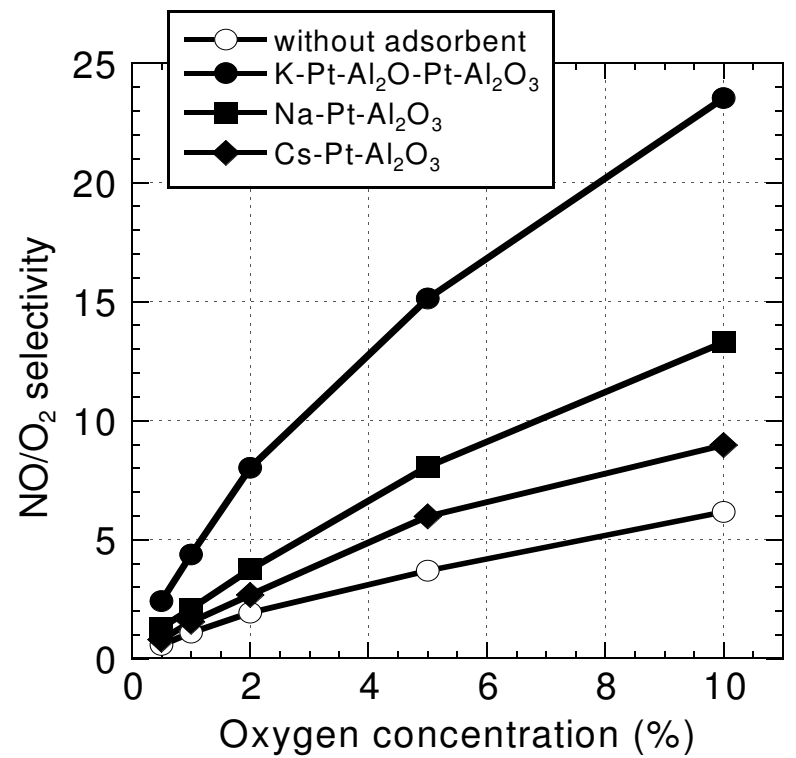

Fig. 20. Dependence of $\mathrm{NO} / \mathrm{O}_{2}$ selectivity on the $\mathrm{O}_{2}$ concentrations for the $\mathrm{YSZ}$ based electrochemical reactor with and without a NOx adsorbent at $500^{\circ} \mathrm{C}$. 


\section{Conclusion}

It was shown that the electrochemical reduction of nitric oxide in an atmosphere containing excess oxygen is not effective due to the low selectivity of the cathode materials. To solve the problem of effective electrochemical reduction of nitric oxide in the presence of the excess oxygen S.Bredikhin et al. (Awano et al., 2004b; Bredikhin et al., 2001a, 2001b) proposed the concept of artificially designed multilayer structure which should operate as an electrode with high selectivity. Our investigations have shown that substitution of traditional cathodes by the multilayer electro-catalytic electrode with an electrochemically assembled nanostructure leads to a dramatic decrease in the value of the electrical power required for NO decomposition. It was shown that multilayer electro-catalytic electrode should consist at list from three main functional layers: Cathode; Electro-catalytic electrode; Covering layer, in order to operate as an electrode with high selectivity. In 2008 K.Hamamoto et.al. (Hamamoto et al., 2008) proposed to use an electrochemical reactor with fourth additional NOx adsorption layer. The values of current efficiency in such reactors increase up to $20 \%$ and the values of the $\mathrm{NO} / \mathrm{O}_{2}$ selectivity up to 25 . These results indicate that this new type of electro-catalytic reactor can be used for practical applications. From our point of view, such systems should substitute traditional catalytic systems for exhaust gas purification.

\section{References}

Armor, J.N., "Catalytic reduction of nitrogen oxides with methane in the presence of excess oxygen: A review", Catalysis Today, 26, 147-158 (1995).

Aronin, A., Abrosimova, G., Bredikhin, S., Matsuda, K., Maeda, K. \& Awano, M., “Structure evolution of a NiO-YSZ Electro-catalytic Electrode", Journal of the American Ceramic Society 88, 5, 1180-1185, (2005).

Awano, M., Bredikhin, S., Aronin, A., Abrosimova, G., Katayama, S. \& Hiramatsu, T., "NOx decomposition by electrochemical reactor with electrochemically assembled multilayer electrode", Solid State Ionics 175, 605-608, (2004).

Awano, M., Fujishiro, Y., Hamamoto, K., Katayama, S. \& Bredikhin, S., “Advances in nanostructured electrochemical reactors for NOx treatment in the presence of oxygen", International Journal of Applied Ceramic Technology, 1 (2), 277-286, (2004).

Baker, R.A. \& Doerr, R.C., Ind. Eng. Chem. Process Des. Dev. 4 (1965), p. 188.

Baker, R.A. \& Doerr, R.C., J. Air Pollut. Control Assoc. 14 (1964), p. 409.

Bosch, H. \& Janssen, F., Catalysis Today, 2, 369 (1988).

Bredikhin, S., Abrosimova, G., Aronin, A. \& Awano, M., "Electrochemical Cells with Multilayer Functional Electrodes", Part I. Reduction-oxidation reactions in a NiOYSZ electro-catalytic electrode, Journal of Ionics , 12, 1, 33-39, (2006).

Bredikhin, S., Abrosimova, G., Aronin, A., Hamamoto, K., Fujishiro, Y., Katayama, S. \& Awano, M., "Pt-YSZ Cathode for Electrochemical Cells with Multilayer Functional Electrode", Journal of the Electrochemical Society 151 (12) J95-J99 (2004).

Bredikhin, S., Maeda, K. \& Awano, M., "Electrochemical cell with two layer cathode for NO decomposition", Journal of Ionics, 7, 109-115, (2001).

Bredikhin, S., Maeda, K. \& Awano, M., "NO decomposition by an electrochemical cell with mixed oxide working electrode", Solid State Ionics 144, 1-9, (2001). 
Bredikhin, S., Maeda, K. \& Awano, M., "Peculiarity of NO decomposition by electrochemical cell with mixed oxide working electrode", Journal of the Electrochemical Society 148, (10), D133-D138, (2001).

Finlayson-Pitts, B.J. \& Pitts, J.N., “Tropospheric Air Pollution: Ozone, Airborne Toxics, Polycyclic Aromatic Hydrocarbons, and Particles", Science 276 (5315), 1045-1051 (1997).

Garin, F., "Mechanism of NOx decomposition", Applied Catalysis A: General 222, (2001), 183.

Gur, T.M. \& Huggins, R.A., "Decomposition of Nitric Oxide on Zirconia in a Solid State Electrochemical Cell", J.Electrochem.Soc. 126, no.6, 1067-1075, (1979).

Hamada, H., Kintaichi, Y., Sasaki, M., Ito, T. \& Tabata, M., Appl. Catal. 64 (1990), p. L1.

Hamamoto, K., Fujishiro, Y. \& Awano, M., "Low temperature NOx Decomposition using electrochemical reactor", Journal of The Electrochemical Society, (In print),(2008).

Hamamoto, K., Fujishiro, Y. \& Awano, M., "Reduction and Reoxidation Reaction of Catalytic Layers in Electrochemical Cells for NOx Decomposition", Journal of The Electrochemical Society, 154 (9) F172-F175, (2007).

Hamamoto,.K., Fujishiro, Y. \& Awano, M., "Intermediate Temperature Electrochemical Reactor for NOx Decomposition", Journal of the Electrochemical Society, 153 (11) D167-D170, (2006).

Hibino, T., "Electrochemical Removal of $\mathrm{NO}$ and $\mathrm{CH}_{4}$ from Oxidizing Atmosphere", Chem. Lett. 927, (1994).

Hibino, T., Inoue, I. \& Sano, M., "Electrochemical reduction of NO by alternating current electrolysis- using yttria-stabilized zirconia as the solid electrolyte; Part I. Characterizations of alternating current electrolysis of NO", Solid State Ionics 130, 19-29, (2000).

Hibino, T., Inoue, I. \& Sano, M., "Electrochemical reduction of NO by alternating current electrolysis using yttria-stabilized zirconia as the solid electrolyte; Part II. Modification of Pd electrode by coating with $\mathrm{Rh}^{\prime \prime}$, Solid State Ionics 130, 31-39, (2000).

Hiramatsu, T., Bredikhin, S., Katayama, S., Shiono, O., Hamamoto, K., Fujishiro, Y. \& Awano, M., "High selective deNO x electrochemical cell with self-assembled electro-catalytic electrode", Journal of Electroceramics, 13 (1-3), 865-870, (2004).

Hwang, H.J., Towata, A., Awano \& Maeda, K., "Sol-gel route to perovskite-type Srsubstituted $\mathrm{LaCoO}_{3}$ thin films and effects of polyethylene glycol on microstructure evolution", Scripta Materialia, 44, 2173, (2001).

Iwamoto, M., Proceedings of Meeting of Catalytic Technology for Removal of Nitrogen Monoxide, Tokyo, Japan, 1990, p. 17

Iwayama, K. \& Wang, X., "Selective decomposition of nitrogen monoxide to nitrogen in the presence of oxygen on $\mathrm{RuO}_{2} / \mathrm{Ag}$ (cathode)/yttria-stabilized zirconia/Pd(anode)", Applied Catalysis B: Environmental, 19, 137 (1998).

Janssen, F. \& Meijer, R., "Quality control of DeNO ${ }_{x}$ catalysts Performance testing, surface analysis and characterization of $\mathrm{DeNO}_{x}$ catalysts", Catalysis Today, 16, 157 (1993).

Kammer K., "Electrochemical DeNOx in solid electrolyte cells-an overview" Applied Catalysis B: Environmental 58, 33-39 (2005).

Klimisch, R.L. \& Barnes, G.J., Environ. Sci. Technol. 6 (1972), p. 543.

Kobayashi, K., Yamaguchi, Sh., Higuchi, T., Shin, Sh. \& Iguchi, Y., Solid State Ionics 135, 643, (2000). 
Lerdau, M.T., Munger, J.W. \& Jacob, D.J., “Enhanced: The $\mathrm{NO}_{2}$ Flux Conundrum”, Science 289 (5488), 2291-2293 (2000).

Libby, W.F., "Promising catalyst for auto exhaust", Science 171, 499-500 (1971).

Lindsay, R., Theobald, A., Gießel, T., Schaff, O., Bradshaw, A.M., Booth, N.A. \& Woodruff, D.P., "The structure of NO on Ni(111) at low coverage", Surface Science 405, L566L572, (1998).

Marwood, M. \& Vayenas, C.G., "Electrochemical Promotion of the Catalytic Reduction of NO by CO on Palladium", Journal of Catalysis, 170, 275 (1997).

Matsuda, K., Kanai, T., Awano, M. \& Maeda, K., "NO decomposition Properties of Lanthanum Manganite Porous Electrode", MRS Proceedings, Vol. 658, G9, 36, 1-5 (2001).

Miura, K., Nakagawa, H., Kitaura, R. \& Satoh, T., “Low-temperature conversion of NO to $\mathrm{N}_{2}$ by use of a novel Ni loaded porous carbone", Chemical Engineering Science 56, 1623 $1629,(2001)$.

Nakatani, J., Ozeki, Y., Sakamoto, K. \& Iwayama, K., “NO Decomposition in the Presence of Excess $\mathrm{O}_{2}$ Using the Electrochemical Cells with Pd Electrodes Treated at High Temperature and Coated with $\mathrm{La}_{1-x} \mathrm{Sr}_{x} \mathrm{CoO}_{3}{ }^{\prime \prime}$, Chem. Lett., no.4, 315-319, (1996).

Nishihata, Y., Mizuki, J., Akao, T., Tanaka, H., Uenishi, M., Kimura, M., Okamoto, T. \& Hamada, N., "Self-regeneration of a Pd-perovskite catalyst for automotive emissions control", Nature 418, 164-167 (2002).

Pancharatnam, S., Huggins, R.A. \& Mason, D.M., "Catalytic Decomposition of Nitric Oxide on Zirconia by Electrolytic Removal of Oxygen", J. Electrochem. Soc. 122, no.7, 869875, (1975).

Parvulescu, V.I., Grange P. \& Delmon, B., “Catalytic removal of NO”, Catalysis Today, 46, 233-316, (1998).

Rickardsson, I., Jönsson, L. \& Nyberg, C., "Influence of surface topology on NO adsorption: $\mathrm{NO}$ on $\mathrm{Ni}(100)$ and $\mathrm{Ni}(510)^{\prime \prime}$, Surface Science 414, 389-395, (1998).

Roth, J.F. \& Doerr , R.C., Ind. Eng. Chem. 53 (1961), p. 293.

Sato S., Hirabayashi, H., Yahiro, H., Mizuno, N. \& Iwamoto, M., Catal. Lett. 12 (1992), p. 193.

Schoonman, J., in: Chowdari, B.V.R. \& Radakrishna, S. (Eds.), Proceedings of the 3rd International Symposium on Solid State Ionics Devices, World Scientific Singapore, 697, (1988).

Simonsen, V.L.E., Find, D., Lilliedal, M., Petersen, R., \& Kammer, K., “Spinels as cathodes for the electrochemical reduction of $\mathrm{O}_{2}$ and $\mathrm{NO}^{\prime \prime}$, Topics in Catalysis Vol. 45, 143-148, (2007).

Wagner, C., in: Delahay, P. \& Tobias, C.W. (Eds.), Advances in Electrochemistry and Electrochemical Engineering, Interscience Publishers, New York, (1966).

Walsh, K.J. \& Fedkiw, P.S., "Nitric oxide reduction using platinum electrodes on yttriastabilized zirconia", Solid State Ionics 93, 17 (1997).

Washman, Eric D., Jayaweera, P., Krishnan, G. \& Sanjurjo, A., "Electrocatalytic reduction of $\mathrm{NO}_{x}$ on $\mathrm{La}_{1-x} \mathrm{~A}_{x} \mathrm{~B}_{1-y} \mathrm{~B}_{y}^{\prime} \mathrm{O}_{3}$ : evidence of electrically enhanced activity", Solid State Ionics 136-137, 775-782, (2000). 


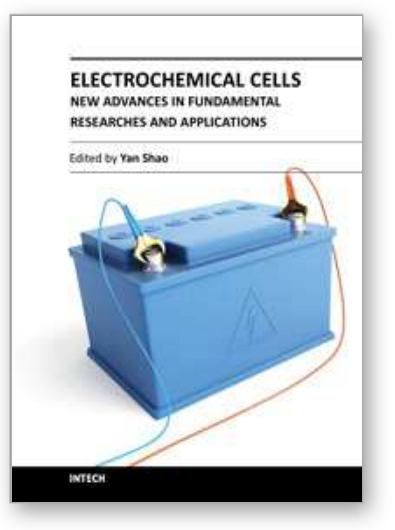

\section{Electrochemical Cells - New Advances in Fundamental Researches and Applications}

Edited by Dr. Yan Shao

ISBN 978-953-51-0032-4

Hard cover, 240 pages

Publisher InTech

Published online 07, March, 2012

Published in print edition March, 2012

Currently the research field of electrochemical cells is a hotspot for scientists and engineers working in advanced frontlines of micro-, nano- and bio-technologies, especially for improving our systems of energy generation and conversation, health care, and environmental protection. With the efforts from the authors and readers, the theoretical and practical development will continue to be advanced and expanded.

\section{How to reference}

In order to correctly reference this scholarly work, feel free to copy and paste the following:

Sergey Bredikhin and Masanobu Awano (2012). Electrochemical Cells with Multilayer Functional Electrodes for NO Decomposition, Electrochemical Cells - New Advances in Fundamental Researches and Applications, Dr. Yan Shao (Ed.), ISBN: 978-953-51-0032-4, InTech, Available from:

http://www.intechopen.com/books/electrochemical-cells-new-advances-in-fundamental-researches-andapplications/electrochemical-cells-with-multilayer-functional-electrodes-for-no-decomposition-

\section{INTECH}

open science | open minds

\section{InTech Europe}

University Campus STeP Ri

Slavka Krautzeka 83/A

51000 Rijeka, Croatia

Phone: +385 (51) 770447

Fax: +385 (51) 686166

www.intechopen.com

\section{InTech China}

Unit 405, Office Block, Hotel Equatorial Shanghai

No.65, Yan An Road (West), Shanghai, 200040, China 中国上海市延安西路65号上海国际贵都大饭店办公楼 405 单元

Phone: +86-21-62489820

Fax: $+86-21-62489821$ 
(C) 2012 The Author(s). Licensee IntechOpen. This is an open access article distributed under the terms of the Creative Commons Attribution 3.0 License, which permits unrestricted use, distribution, and reproduction in any medium, provided the original work is properly cited. 